\title{
Genetic Analysis of Deletions of R100-1 that are Both Transfer- deficient and Tetracycline-sensitive
}

\author{
By T. J. FOSTER \\ Bacteriology Department, Trinity College, Dublin 2, Eire \\ AND N. S. WILLETTS \\ Department of Molecular Biology, University of Edinburgh, Kings Buildings, \\ Edinburgh $\mathrm{EH}_{9}{ }_{3} \mathrm{JR}$
}

(Received 6 August 1975)

SUMMARY

The extent of the deletions of five Tets ${ }^{\mathrm{s}} \mathrm{Tr}^{-}$mutants of RIO0-I was determined by complementation experiments with wild-type and tra mutants of Flac. The presence or absence of the origin of transfer on the mutants was also investigated. Using the results, a tentative map of this region of the $\mathrm{R}$ factor was drawn: it was essentially similar to the analogous region of the $E$. coli KI $2 \mathrm{~F}$ factor, except that tet was located between $\operatorname{traJ}$ and $\operatorname{traA}$.

Some of the deletions had removed the promoter for the transfer operon. This allowed detection of the transcription of $\operatorname{traC}$ and distal genes from a weak, traJ-independent promoter. This is probably the Is 2 promoter, since RIOO-I carries an Is2 insertion sequence located immediately to the left of $t r a C$ in the correct orientation. Since neither the transfer operon promoter nor the Is 2 promoter seemed to be required for transcription of $\operatorname{traI}$, it was concluded that, unlike the F factor, this was located in a separate operon.

\section{INTRODUCTION}

Amongst a series of spontaneous tetracycline-sensitive $\left(\mathrm{Tet}^{\mathrm{s}}\right)$ mutants of Rioo-I, a high proportion (about 50\%) were found to be transfer-deficient (Foster, I975). We have examined some of these putative Tet $^{\mathrm{s}} \mathrm{Tra}^{-} \mathrm{R}$ I00-I deletion mutants further to determine which transfer genes have been lost. For this, complementation between the mutants and a series of Flac tra point mutants (Achtman, Willetts \& Clark, I972) was measured. It has been shown that such complementation is possible, although with limitations (Ohtsubo, Nishimura \& Hirota, 1970; Willetts, 1971). The presence or absence of the origin of transfer (Willetts, I972) on the Tets Tra- Rioo-I mutants was also determined, and their levels of surface exclusion were measured. The gene(s) for surface exclusion by Rioo-I is co-controlled with the transfer genes (Willetts \& Maule, I974), and is probably located in the transfer region.

These studies have enabled us to infer the probable extent of the deletions carried by the Tets ${ }^{\text {Tra }}{ }^{-}$mutants. Furthermore, removal of the promoter for the transfer operon by some of the deletions allowed us to demonstrate the presence of a second, weak promoter within the tra operon, able to transcribe traC and distal genes. 


\section{METHODS}

Bacterial host strains. The strains used were $\mathrm{JC} 3272$ (lac his trp lys str-r), ED2030 (lac trp spc-r recA), DUIOOO (lac his trp lys str-r nal-r), DUI004 (pro met rif-r), and DUIO25 (lac his str-r rif-r). Strain ED2030 is a gal his ${ }^{+}$recA56 derivative of JC5455, and DU1000 is a spontaneous $\mathrm{Nal}^{\mathrm{r}}$ mutant of $\mathrm{JC} 3272$; the derivations of $\mathrm{JC} 3272$ and $\mathrm{JC} 5455$ were given by Achtman, Willetts \& Clark (1971). Strains DUI004 and DUI025 are spontaneous Rifr mutants of 55-3 (Clowes \& Hayes, 1968) and E. coli 236 (from the culture collection of the Genetics Department, Trinity College, Dublin), respectively.

Plasmids. The Tets $\mathrm{R}$ factor mutants were derived from R $100-\mathrm{I}$, a 'derepressed' mutant of R100 (Egawa \& Hirota, I962), which confers resistance to tetracycline (Tet), chloramphenicol $(\mathrm{Chl})$, streptomycin (Str) and sulphonamides (Sul). The mutants were isolated by penicillin selection in non-mutagenized cultures in the presence of tetracycline; each culture was started from an independent clone (Foster, 1975). $\mathrm{pDU}_{3}$ is a $\mathrm{Tra}^{+} \mathrm{Tet}^{\mathrm{s}}$ point mutant, while pDUior, pDUI03, pDUı06, pDUi I I and pDUi 13 are Tet $^{\mathrm{s}}$ Tra $^{-}$mutants; pDUIII* indicates that pDUII i is integrated into the host chromosome. pDU 5 is a $\mathrm{Ch}^{\mathrm{r}}$ revertant of Ri 00-99, a Chls Tets $^{\mathrm{s}}$ double mutant derived from R I00-I (Hashimoto \& Hirota, I966), and pDU Ioo is a $\mathrm{Ch}^{\mathrm{s}}$ point mutant of Rioo-I (Foster \& Howe, 1973).

The wild-type and amber-suppressible transfer-deficient Flac elements have been described (Achtman et al., 197I, 1972; Willetts \& Achtman, 1972).

Media. Nutrient broth and nutrient agar were those of Foster \& Walsh (1974). Minimal salts agar contained $(\mathrm{g} / \mathrm{l}): \mathrm{K}_{2} \mathrm{HPO}_{4}, 7 ; \mathrm{KH}_{2} \mathrm{PO}_{4}, 3 ; \mathrm{MgSO}_{4}, 0 \cdot 2 ;\left(\mathrm{NH}_{4}\right)_{2} \mathrm{SO}_{4}$, I; Difco Bacto agar, 20. MacConkey agar contained $40 \mathrm{~g}$ Oxoid peptone, $5 \mathrm{~g} \mathrm{NaCl}$, $10 \mathrm{~g}$ sodium taurocholate, $10 \mathrm{~g}$ lactose, $0.01 \%$ neutral red and $2 \mathrm{~g}$ Difco Bacto agar per litre, $\mathrm{pH} 7 \cdot 0$. Sugars were added to a final concentration of $\mathrm{I} \%$, L-amino acids to $20 \mu \mathrm{g} / \mathrm{ml}$, tetracycline, chloramphenicol and nalidixic acid to $20 \mu \mathrm{g} / \mathrm{ml}$, rifampicin to $40 \mu \mathrm{g} / \mathrm{ml}$ and spectinomycin to Io $\mu \mathrm{g} / \mathrm{ml}$.

Tetracycline, chloramphenicol, nalidixic acid, rifampicin and spectinomycin were gifts from Lederle Laboratories, Parke Davis, Winthrop, Ciba and Upjohn respectively.

Conjugational complementation tests. The Tets $\mathrm{Tra}^{-} \mathrm{RIO0-I}$ deletion mutants were transduced into the recA strain ED2030, using PI $k c$ and selecting for Chlr progeny. These derivatives were then used as recipients in matings with $\mathrm{Su}^{+}$donor strains carrying ambersuppressible Flac tra mutants and $\mathrm{Lac}^{+} \mathrm{Ch}^{\mathrm{r}}$ progeny were selected. The strains carrying both RIOO-I and Flac elements were purified on MacConkey agar containing chloramphenicol. Flac tra derivatives of ED2030 $\left(\mathrm{R}^{-}\right)$used in control matings were selected and purified on MacConkey agar containing spectinomycin.

pDUIII* could not be transduced to ED2030 (see below); it was therefore transduced to DUI000, and Flac tra derivatives of this strain were constructed, selecting $\mathrm{Lac}^{+} \mathrm{Chl}^{\mathrm{r}}$ $\left[\mathrm{Nal}^{\mathrm{r}}\right]$ progeny.

Cultures were prepared for mating by diluting overnight broth cultures $\mathrm{I}: 10$ in fresh broth and incubating at $37^{\circ} \mathrm{C}$ without shaking for $4 \mathrm{~h}$. The plasmid-containing donor culture $(0.5 \mathrm{ml})$ was then mixed with $4.5 \mathrm{ml}$ of a culture of the recipient strain DU I000 (or DU I025 for donor strains carrying pDU I I I*), and incubated at $37^{\circ} \mathrm{C}$ for $30 \mathrm{~min}$. Suitable dilutions were then spread on media selective for $\mathrm{Lac}^{+}\left[\mathrm{Nal}^{\mathrm{r}}\right]$ or $\mathrm{Ch}^{\mathrm{r}}\left[\mathrm{Nal}{ }^{\mathrm{r}}\right]$ progeny (or $\left[\mathrm{Rif}^{\mathrm{r}}\right]$ progeny of DUI025).

Origin of transfer. The method used to determine whether the Tet ${ }^{\mathrm{s}} \mathrm{Tra}^{-} \mathrm{R}$ Ioo-I mutants carried the putative R100-I origin of transfer was based upon that of Willetts (I972). A $0.1 \mathrm{ml}$ portion of an exponential culture of DUI004 (pro met nal-s) carrying pDU IoO 
( Tet $^{\mathrm{r}} \mathrm{Ch} \mathrm{s}^{\mathrm{s}}$ ) was mixed with $\mathrm{O}^{-} \mathrm{I} \mathrm{ml}$ of a shaken overnight ( $\mathrm{R}^{-}$phenocopy) culture of ED2030 ( $\mathrm{RecA}^{-} \mathrm{Nal}^{\mathrm{s}}$ ) carrying the $\mathrm{Tet}^{\mathrm{s}} \mathrm{Tra}^{-} \mathrm{R} 100-\mathrm{I}$ mutant, and the mixture incubated for $40 \mathrm{~min}$. Broth $(0.8 \mathrm{ml})$ was added, followed by incubation for a further $40 \mathrm{~min}$ to allow expression of the transfer genes in the resultant ED2030 heterozygotes. At this stage the number of ED2030 cells which had received pDU 100 was assayed by plating on medium selective for $\mathrm{Tet}^{\mathrm{r}}\left[\mathrm{Pro}^{+} \mathrm{Met}^{+}\right]$progeny of this strain. One $\mathrm{ml}$ of an exponential culture of DUIOOO $\left.(\mathrm{Nal})^{\mathrm{r}}\right)$ was then added, and after $30 \mathrm{~min}$ incubation, dilutions were plated on medium selective for $\mathrm{Ch}^{\mathrm{r}}\left[\mathrm{Nal}^{\mathrm{r}}\right]$ progeny.

Surface exclusion indices. For measurement of the levels of surface exclusion by the $\mathrm{Tet}^{\mathrm{s}} \mathrm{Tra}^{-}$RIoo-I mutants, derivatives of Duloo4 were constructed by transduction. One $\mathrm{ml}$ of exponential cultures of these strains ( Rif $^{r}$ ) was mixed with $\mathrm{I} \mathrm{ml}$ of a similar culture of DU $1000\left(\mathrm{Rif}^{\mathrm{s}}\right)$ carrying pDU $100\left(\mathrm{Tet}^{\mathrm{r}} \mathrm{Ch} \mathrm{Cl}^{\mathrm{s}}\right)$. After $60 \mathrm{~min}$, dilutions were plated on medium selective for $\mathrm{Tet}^{\mathrm{r}}\left(\mathrm{His}^{+} \mathrm{Trp}^{+} \mathrm{Lys}^{+} \mathrm{Rif}^{\mathrm{r}}\right)$ progeny. For pDU $\mathrm{II}^{*}$, which was probably integrated into the chromosome of DUIO0O $(\mathrm{Nal})$, surface exclusion levels were measured by transferring pDUIOO from DUIOO4 $\left(\mathrm{Nal}^{\mathrm{s}}\right)$ and selecting $\mathrm{Tet}^{\mathrm{r}}\left[\mathrm{Pro}^{+} \mathrm{Met}^{+} \mathrm{Nal}^{\mathrm{r}}\right]$ progeny.

\section{RESULTS}

\section{The Tet ${ }^{s}$ Tra ${ }^{-}$RIoo-I mutants}

A series of spontaneous Tets mutants of RIoo-I was isolated by Foster (1975) and many of these were found to be completely transfer-deficient and resistant to the male specific phages MS2 and Mi3. They retained other properties of the Rioo-I parent such as the $\mathrm{Ch}^{\mathrm{r}} \mathrm{Str}^{\mathrm{r}} \mathrm{Sul}^{\mathrm{r}}$ markers, and incompatibility towards other group FII plasmids. They could be transduced by $\mathrm{P}_{\mathrm{I}} k c$ to both $\mathrm{Rec}^{+}$and $\mathrm{RecA}^{-}$strains of E. coli, and are therefore presumed to retain their autonomous plasmid state. RIO0-I mutants of this type are pDU1OI, pDUio3, pDUio6 and pDUiı3.

pDUII is a further Tets Tra $^{-}$Rioo-I mutant, but which in addition seems to have suffered loss of a function(s) affecting replication. When first isolated, it was readily lost from cultures grown in the absence of chloramphenicol $(99 \%$ of the cells were Chls after overnight growth in broth). However, after several months' storage on a Dorset Egg slope, a stable variant, $\mathrm{pDU} \mathrm{III}_{\mathrm{I}}$ * was isolated. $\mathrm{pDU} \mathrm{III}^{*}$ was transduced at a roo-fold lower frequency than the other $\mathrm{Tet}^{\mathrm{s}} \mathrm{Tra}^{-} \mathrm{R}$ IOO-I mutants to a $\mathrm{Rec}^{+}$recipient, and not at all to a $\mathrm{RecA}^{-}$recipient; in addition, it was compatible with pDUIoo (a $\mathrm{Ch}^{\mathrm{s}} \mathrm{Tet}^{\mathrm{r}}$ mutant of RIOO-I). pDUIII* is therefore presumed to be integrated into the host chromosome since it has lost both replication and incompatibility gene(s) and can be inherited only as a result of recombination.

\section{Conjugational complementation tests}

RecA- strains carrying both a Tets Tra $^{-}$R100-I mutant and an Flac tra- element were constructed, and their donor abilities measured, as described in Methods. Most of the transfer gene products of F and RIoo-I are interchangeable (Ohtsubo et al., 1970; Willetts, 197I); however, the products of the tral and traJ genes are plasmid-specific, since RIOO-I gives only low levels of complementation with traI or traJ mutants of F (Willetts, 197I). In addition, RIO0-I will not initiate transfer from the F origin of transfer (Reeves \& Willetts, 1974), and it has been hypothesized that this is due to the different specificities of the traI products (Willetts, 1972). The traJ product is required for expression of all the other F transfer genes, including traI (Finnegan \& Willetts, 1973), which are located in a single operon (Helmuth \& Achtman, 1974). 


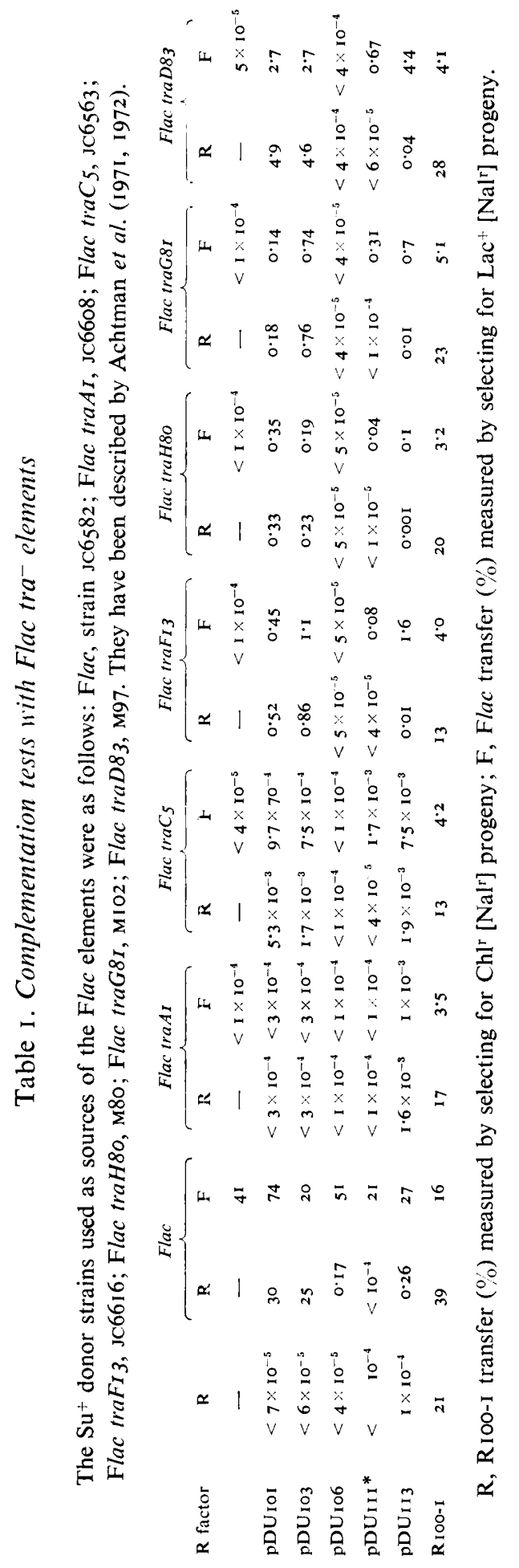




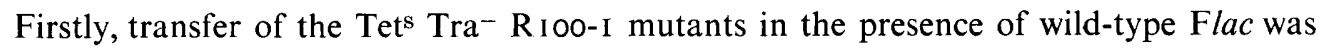
measured (Table I). Two of the Rioo-I mutants (pDUioi and pDUio3) were transferred at high levels similar to that of the Flac element itself. Two further mutants (pDU106 and pDUII3) were transferred at Ioo-fold lower levels, while pDUiII* was never transferred, consistent with a chromosomal location for this element. The two $\mathrm{Tet}^{\mathrm{s}} \mathrm{Tra}^{-} \mathrm{R}$ Ioo-I mutants transferring at high frequency in the presence of wild-type Flac must be $\mathrm{traJ}^{+}$and $\mathrm{traI}^{+}$ and carry ori (the Rioo-I origin of transfer sequence), while the two transferring at low frequency must have lost at least one of these loci.

Complementation experiments with Flac elements mutant in several non-plasmid-specific genes were then performed (Table I). Complementation in, and transfer from, the $\operatorname{rec} A$ host used was relatively poor, compared with the approximately $100 \%$ values found in $\mathrm{Rec}^{+}$strains (Willetts, 1971). We interpret zero levels of transfer of the Flac tra ${ }^{-}$mutants to mean that the $\mathrm{R}$ factor deletion has removed all or part of the analogous tra gene, and low or very low levels to indicate that the gene is still present. As expected, the levels of transfer of the Rioo-I deletion mutants were the same as those of the Flac tra- elements for pDUior and pDUIo3 (shown above to be $\mathrm{raJ}^{+} \mathrm{traI}^{+} \mathrm{ori}^{+}$), about Ioo-fold lower for pDUiI 3 (which has lost traJ; see below), and zero for pDU I I * and pDUıo6 (ori- ${ }^{-}$; see below).

pDU 106 appeared to have suffered the longest deletion, since it gave no complementation with any of the Flac tra- mutants tested. pDUioi, pDUI03 and pDU 11 * were similar to each other in having lost $\operatorname{traA}$ but retaining $\operatorname{traC}$ and later genes in the transfer operon, while pDUi 3 retained $\operatorname{traA}$ as well.

However, although pDU I 3 retained $\operatorname{traA}$, the very low level of complementation indicated a very low level of expression. A likely explanation for this is that pDU I 3 has lost traJ, the product of which is required for expression of the transfer operon (Finnegan \& Willetts, 1973); only a low residual level of expression of traA can therefore occur.

Although the deletions carried by pDUior, pDUio3 and pDUIII*, which include traA, should have totally removed the promoter for the transfer operon $\left(\mathrm{p}_{A}\right)$ located between tet and $\operatorname{traA}$, the genes $\operatorname{traC}, \operatorname{traF}, \operatorname{traH}, \operatorname{tr} a G$ and $\operatorname{traD}$ were expressed at levels sufficient to give approximately $0.1,20,5,10$ and $50 \%$ complementation of the appropriate Flac tramutants, respectively (taking complementation by RIO0-I as $100 \%$ ). Similar levels of complementation for these genes in the tra operon were also given by pDUII3. Since the use of a RecA- host should have prevented recombination between homologous regions of $F$ and Rioo-I (no recombinants were in fact found) and therefore any expression of an RIOO-I tra gene from an F promoter, we propose that a weak promoter is located to the left of $\operatorname{traC}$. This would allow partial expression of $\operatorname{traC}$ and later genes in the tra operon. The different levels of retransfer of the $\mathrm{traC}^{-}, \mathrm{traF}^{-}, \mathrm{traH}^{-}, \mathrm{traG}^{-}$and $\mathrm{traD}^{-}$mutants of Flac might be inversely related to the amounts of these gene products required for transfer, and perhaps also to the quantitative abilities of the RIO0-I products to replace those of Flac.

\section{The origin of transfer}

According to the previous section, pDUio a and pDUI03 should retain the Rioo-I origin of transfer, while pDUI06 and pDUI 13 might have lost this locus. The presence or absence of the origin sequence on these four RIOO-I mutants was therefore determined directly. For this, a $\mathrm{Tra}^{+} \mathrm{Tet}^{\mathrm{r}} \mathrm{Chls} \mathrm{R}$ factor (pDUIOO) was transferred into the ED2030 ( $\mathrm{RecA}^{-}$) derivatives carrying the $\mathrm{Tra}^{-} \mathrm{Tet}^{\mathrm{s}} \mathrm{Ch}^{\mathrm{r}} \mathrm{R}$ 100-I mutants, and the transfer of chloramphenicol resistance from the resultant $\mathrm{Tra}^{+}$heterozygotes was measured (Table 2).

The three Rioo-I mutants pDUior, pDUio3 and pDUis3 were all transferred at 
Table 2. Origin of transfer and surface exclusion experiments

\begin{tabular}{|c|c|c|}
\hline $\begin{array}{l}\text { Rioo-I } \\
\text { mutant }\end{array}$ & $\begin{array}{c}\mathrm{Chl}^{\mathrm{r}} \mathrm{Nal}^{\mathrm{r}} \text { progeny// } \\
\text { heterozygotes } \dagger\end{array}$ & $\begin{array}{c}\text { Surface exclusion } \\
\text { index }\end{array}$ \\
\hline pDUIOI & $2 \cdot 4$ & $9 \cdot 3$ \\
\hline pDUIO3 & $8 \cdot 7$ & $5 \cdot 9$ \\
\hline pDU 106 & $3.1 \times 10^{-4}$ & 0.79 \\
\hline pDU I I I * & NT & $2 \cdot 0$ \\
\hline pDU I 3 & 0.17 & $6 \cdot 4$ \\
\hline $\mathrm{pDU}_{3}$ & NT & 43 \\
\hline pDU5 & NT & 51 \\
\hline
\end{tabular}

$\dagger$ The numbers represent the frequencies of transfer of the $\mathrm{Tet}^{\mathrm{s}} \mathrm{Tra}^{-} \mathrm{Ch}{ }^{\mathrm{r}} \mathrm{R}$ 100-I mutants per 100 heterozygous cells also carrying the $\mathrm{Tet}^{\mathrm{r}} \mathrm{Tra}^{+} \mathrm{Chl}^{\mathrm{s}}$ element $\mathrm{pDU}$ ioo.

$¥$ The ratio of the number of Tetr progeny of DUIO04 (DU1000 in the case of pDUIII*) to the number obtained from its derivatives carrying a Tet $^{\mathrm{s}} \mathrm{Tra}^{-}$R Ioo-I mutant, measured in crosses with a donor strain carrying the Tetr element pDU Ioo.

NT, not tested.

significant levels, confirming that all these carry the origin sequence. pDU106, however, was transferred at a very low frequency, suggesting that it had lost the origin sequence.

\section{Surface exclusion}

$\mathrm{R}$ I00-I determines a surface exclusion system $\left(\mathrm{Sfx}_{\mathrm{IV}}\right)$ different from that of $\mathrm{F}\left(\mathrm{Sf}_{\mathrm{I}}\right)$; like that of F, however, it is inhibited during transfer inhibition or in stationary-phase cells, and the gene(s) responsible may therefore form part of the transfer operon (Willetts \& Maule, 1974). The surface exclusion gene (traS) of $\mathrm{F}$ has been located between $\operatorname{tra} G$ and $\operatorname{traD}$ (Willetts, 1974).

The surface exclusion indices of cells carrying the Tets $\mathrm{Tra}^{-} \mathrm{R} 100-\mathrm{I}$ mutants were measured in matings with a donor strain carrying pDU 100 ( $\mathrm{Tet}^{\mathrm{r}}$ ) (Table 2). Control experiments showed that the Tets $\mathrm{Tra}^{+}$Rioo-I point mutants $\mathrm{pDU}_{3}$ and $\mathrm{pDU}_{5}$ had indices of about 50, similar to the levels found previously for RIO0-I. The four Tets Tra $^{-}$Rioo-I mutants carrying deletions ending before $\operatorname{traC}$ all had indices of 2 to 9 , suggesting that they retained traS but expressed it at a reduced level from the weak promoter located to the left of $t r a C$. pDUIo6 showed no surface exclusion, consistent with a location for the RIO0-I surface exclusion genes similar to that of $\operatorname{traS}$ on $\mathrm{F}$, and with the previous results which suggest that pDUio6 carries a deletion removing both $\mathrm{p}_{\mathrm{A}}$ and the weak promoter, and possibly all the tra genes including traS.

\section{DISCUSSION}

Perhaps the most interesting of our findings is that a weak promoter is located within the Rioo-I transfer region to the left of $t r a C$. Hu et al. (1975) showed that Rioo-I carries an Is2 sequence inserted at co-ordinates 67.5 to $68.9 \mathrm{~kb}$ within the tra region of R $100-\mathrm{I}$, in the orientation such that it should be able to initiate constitutive transcription of the later tra genes. This location on RIOO-I corresponds to co-ordinate $7 \mathrm{I} \cdot 2 \mathrm{~kb}$ on F (Sharp, Cohen \& Davidson, 1973), which does not carry a similar Is2 insertion, while traC is known to be located to the right of $72.9 \mathrm{~kb}$ (Sharp et al., 1972). It is therefore most probable that the expression of traC through traD that we have observed when the promoter for the transfer operon $\left(\mathrm{p}_{\mathrm{A}}\right)$ is deleted together with the tet gene, is due to transcription from the Is 2 promoter $\left(\mathrm{p}_{\mathrm{Is} 2}\right)$. Assuming that pDUII 3 is traJ $^{-}$, this transcription was, as expected, independent of the presence of the traJ product. 


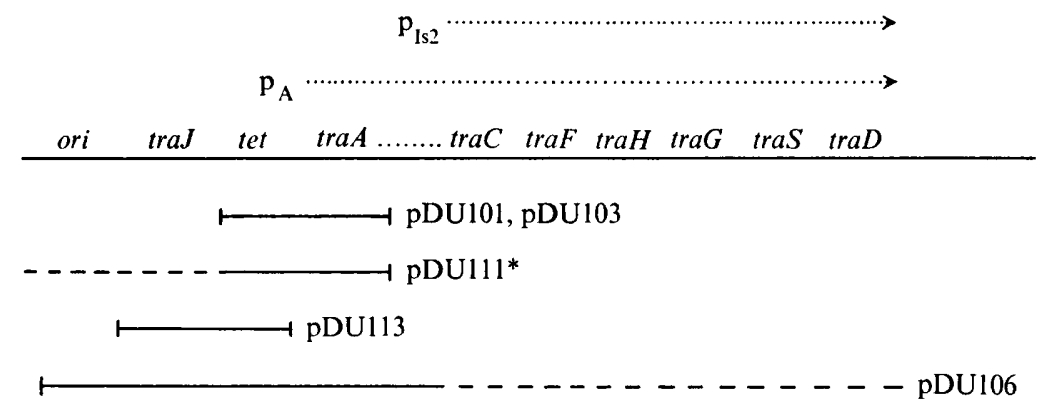

Fig. I. Deletion map of the transfer region of Rio0-I. Broken lines indicate that it is not known whether the deletion covers this region. The dotted lines show transcription from $p_{A}$ and $p_{\text {Is } 2}$ respectively. The order of $\operatorname{traC}, \operatorname{traF}, \operatorname{tra} H, \operatorname{tra}, \operatorname{tra} S$ and $\operatorname{tra} D$ was not determined in these studies, and is assumed to be the same as for F (Ippen-Ihler et al., 1972).

Expression of the later tra genes from $\mathrm{p}_{\mathrm{Is} 2}$ will also explain the complementation properties of Rio0-I 'traX $X^{-}$' mutants (Ohtsubo et al., 1970) and of Rio0-I mutants with $\lambda$ prophage inserted into traA (W. Dempsey and N. S. Willetts, unpublished data). In both cases, reduced levels of complementation with Flac elements mutant in later genes of the tra operon are observed, and no complementation with those mutant in genes located before traC.

Since pDUior and pDUI03 are transferred at high levels in the presence of wild-type Flac, even though they have lost $\mathrm{p}_{\mathrm{A}}$, the necessary $\mathrm{R}$ Ioo traI product must be obtained by transcription from a promoter other than $p_{A}$. This is unlikely to be $p_{I 82}$, since although $\operatorname{traC}$ to $\operatorname{traD}$ are expressed from $\mathrm{p}_{\mathrm{I} \kappa 2}$, traI is apparently not. Thus pDUII3 should retain traI if it is at the end of the transfer operon distal to $\operatorname{tra} D$, but its low transfer in the presence of wild-type Flac suggests that this traI gene is not expressed. Furthermore, the low (I \%) level of transfer of RIO0 from a cell carrying R 100 and Flac traO- (Finnegan \& Willetts, 1973), shows that expression of the R $100 \mathrm{tral}$ gene is dependent upon expression of the R Ioo traJ gene (this being the immediate site of action of transfer inhibition), whereas expression from $\mathrm{p}_{\mathrm{Is} 2}$ is traJ-independent. We conclude that, unlike the traI gene of $\mathrm{F}$, which is the last member of the transfer operon (Helmuth \& Achtman, 1974), the traI gene of RIOO is in a separate operon transcribed by a separate promoter. The location of tral on $\mathrm{R} r 00$ may not be near to $\operatorname{tra} D$, as in $\mathrm{F}$, but elsewhere; this remains to be determined.

A tentative map of the region of RI00-I studied is presented in Fig. I, summarizing the extents of the deletions carried by the five Tets Tra $^{-}$RIOO-I mutants. The location of tet near to $\operatorname{tra} A$ is consistent with the electron-microscope heteroduplex mapping studies of Sharp et al. (1972) and the genetic mapping studies of Yoshikawa (1974) and W. Dempsey and N. S. Willetts (unpublished data).

T.J.F. thanks the National Science Council and the Medical Research Council of Ireland for grants.

\section{REFERENCES}

Achtman, M., Willetts, N.S. \& Clark, A. J. (1971). Beginning a genetic analysis of conjugational transfer determined by the $\mathrm{F}$ factor in Escherichia coli by isolation and characterization of transferdeficient mutants. Journal of Bacteriology ro6, 529-538.

Achtman, M., Willetis, N. S. \& Clark, A. J. (I972). Conjugational complementation analysis of transferdeficient mutants of Flac in Escherichia coli. Journal of Bacteriology 110, 83 I-842.

Clowes, R. C. \& Hayes, W. (1968). Experiments in Microbial Genetics. Oxford and Edinburgh: Blackwell Scientific Publications. 
Egawa, R. \& Hirota, Y. (1962). Inhibition of fertility by multiple-drug-resistance factor (R) in Escherichia coli KI 2. Japanese Journal of Genetics 37, 66-69.

Finnegan, D. \& Willetts, N.S. (I973). The site of action of the F transfer inhibitor. Molecular and General Genetics 127, 307-316.

Foster, T. J. (I975). Tetracycline-sensitive mutants of the F-like R factors Rioo and Rioo-I. Molecular and General Genetics 137, 85-88.

Foster, T. J. \& Howe, T. G. B. (1973). Deletion map of the chloramphenicol resistance region of RI and Rioo-I. Journal of Bacteriology 116, 1062-1063.

Foster, T. J. \& Walsh, A. (1974). Phenotypic characterization of R-factor tetracycline resistance determinants. Genetical Research 24, 333-343.

Hashimoto, H.\& HiRota, H. (I966). Gene recombination and segregation of resistance transfer factor $\mathrm{R}$ in Escherichia coli. Journal of Bacteriology 91, 5I-62.

Helmuth, R. \& Achtman, M. (1974). The F factor carries an operon of more than $15 \times 10^{6}$ daltons coding for DNA transfer and surface exclusion. Microbiology $\mathbf{1}, 95-103$.

Hu, S., Ohtsubo, E., Davidson, N. \& Saedler, H. (1975). Electron microscope heteroduplex studies of sequence relations among bacterial plasmids: identification and mapping of the insertion sequences Is I and Is2 in F and R plasmids. Journal of Bacteriology 122, 764-775.

IPPEN-Ihler, K., Achrman, M. \& Willetts, N. S. (1972). Deletion map of the E. coli. KI 2 sex factor F: the order of eleven transfer cistrons. Journal of Bacteriology I Io, 857-863.

Ohtsubo, E., Nishimura, Y. \& Hirota, Y. (1970). Transfer-defective mutants of sex factors in E. coli. I. Defective mutants and complementation analysis. Genetics 64, 173-I 88.

ReEves, P. \& Willetts, N. S. (1974). Plasmid specificity of the origin of transfer of sex factor F: Journal of Bacteriology 120, I 25-130.

Sharp, P. A., Cohen, S. N. \& Davidson, N. (1973). Electron microscope heteroduplex studies of sequence relations among plasmids of Escherichia coli. II. Structure of drug resistance (R) factors and F factors. Journal of Molecular Biology 75, 235-255.

Sharp, P. A., Hsu, M., Ohtsubo, E. \& Davidson, N. (1972). Electron microscope heteroduplex studies of sequence relations among plasmids of E. coli. I. Structure of F-prime factors. Journal of Molecular Biology 71, 47I-497.

Willetts, N. S. (1971). Plasmid specificity of two proteins required for conjugation in E. coli KI 2. Nature New Biology 230, I 83-I 85 .

WiLleTtS, N. S. (I972). Location of the origin of transfer of the sex factor F. Journal of Bacteriology II2, 773-778.

Willetts, N.S. (1974). Mapping loci for surface exclusion and incompatibility on the F factor of Escherichia coli K-I 2. Journal of Bacteriology I18, 778-782.

Willetts, N. S. \& Achtman, M. (1972). Genetic analysis of transfer by the Escherichia coli sex factor F, using PI transductional complementation. Journal of Bacteriology 110, 843-85I.

Willetts, N. S. \& Maule, J. (1974). Interactions between the surface exclusion systems of some F-like plasmids. Genetical Research 24, 81-89.

Yoshikawa, M. (1974). Identification and mapping of the replication genes of an R factor, R $100-\mathrm{I}$, integrated into the chromosome of Escherichia coli K-1 2. Journal of Bacteriology 118, I1 23-I I 3 I. 